\title{
Mania following ketamine abuse
}

This article was published in the following Dove Press journal:

Neuropsychiatric Disease and Treatment

27 January 2016

Number of times this article has been viewed

\author{
Yuan-Yuan Lu' \\ Chieh-Hsin Lin ${ }^{2,3}$ \\ Hsien-Yuan Lane 1,2,4 \\ 'Department of Psychiatry, China \\ Medical University Hospital, \\ ${ }^{2}$ Graduate Institute of Clinical Medical \\ Science, China Medical University, \\ Taichung, ${ }^{3}$ Department of Psychiatry, \\ Kaohsiung Chang Gung Memorial \\ Hospital, Chang Gung University \\ College of Medicine, Kaohsiung, \\ ${ }^{4}$ Center for Drug Abuse and \\ Addiction, China Medical University \\ Hospital, Taichung, Taiwan
}

\begin{abstract}
Ketamine, a noncompetitive antagonist of the $N$-methyl-D-aspartate (NMDA) receptor, has multiple clinical uses. On the other hand, ketamine abuse or recreational use has been gaining increasing attention. Induction of mania and psychotic symptoms has been reported in a patient receiving IV ketamine therapy for reflex sympathetic dystrophy. We here report a 26 year-old man who abused ketamine by inhalation for 12 months and developed manic-like symptoms after ketamine use. This case suggests a possible relationship between manic symptoms and ketamine abuse. To the best of our knowledge, this may be the first report regarding mania after recreational use of ketamine.
\end{abstract}

Keywords: ketamine, mania, antidepressant, bipolar

\section{Introduction}

Ketamine is a noncompetitive antagonist of the $N$-methyl-D-aspartate (NMDA) receptor, a major subtype of glutamate receptors. It has multiple clinical uses. Recent studies have shown that ketamine has antidepressant activity. ${ }^{1,2}$ Induction of mania and psychotic symptoms has been reported in a patient receiving intravenous (IV) ketamine therapy for reflex sympathetic dystrophy. ${ }^{3}$ Recently, ketamine abuse or recreational use has been gaining increasing attention. ${ }^{4}$

More recently, ketamine has become popular in many countries including USA as a "club drug", often used by teens and young adults. However, whether ketamine abuse via other routes of administration such as inhalation can also induce mania remains unclear. We here report a patient who developed manic symptoms following ketamine abuse by inhalation. Ethical approval from a review board was not required for this case report, as the patient was under regular therapy and his case was not intended to be used for research. Patient consent was not required to report this case.

\section{Case report}

A 26-year-old Han Taiwanese man had suffered from Tourette syndrome and obsessive-compulsive disorder since he was 12 years old and started to abuse ketamine by inhalation from 22 years old. He denied any mood disorder before using ketamine or other substance abuse/dependence until he started to abuse ketamine by inhalation. Initially, he took ketamine $5 \mathrm{~g} / \mathrm{wk}$ for several weeks and then $10-15 \mathrm{~g} / \mathrm{wk}$ for months (with a total duration of 12 months). Since his first time of ketamine use, he had experienced marked euphoria, labile mood, dissociation, and auditory hallucinations, and these symptoms vanished after hours. Even during the following 5 months after he stopped use of ketamine, he still had persistent elated mood, increased goal-directed activity with more energy, decreased sleep need, and fewer obsessive-compulsive behaviors. After the manic-like period, his mood gradually shifted to a depressive state. Approximately 7 months after stopping ketamine use,
Correspondence: Hsien-Yuan Lane Department of Psychiatry, China Medical University Hospital, 2 Yude Road,

Taichung 40447, Taiwan

Tel +886 422052 I 2 I ext I855

Email hylane@gmail.com (c) (i) (5) 2016 Lu et al. This work is published and licensed by Dove Medical Press Limited. The full terms of this license are available at https://www.dovepress.com/terms.php BY NC and incorporate the Creative Commons Attribution - Non Commercial (unported, v3.0) License (http://creativecommons.org/licenses/by-nd/3.0). By accessing the work you for commercial use of this work, please see paragraphs 4.2 and 5 of our Terms (https://www.dovepress.com/terms.php). 
a major depressive episode occurred, with worsening of obsessive-compulsive symptoms. Therefore, he was followed-up at our outpatient clinic for 5 months. However, due to poor drug adherence and poor treatment response, he was then hospitalized to our psychiatric ward, where he achieved full remission from the major depressive episode and partial remission from obsessive-compulsive disorder with sertraline $200 \mathrm{mg} / \mathrm{d}$ and aripiprazole $10 \mathrm{mg} / \mathrm{d}$ for 3 weeks. He continued this treatment to keep a stable mood with minimal obsessive-compulsive symptoms for at least 21 months during outpatient follow-up.

\section{Discussion}

The antidepressant effects of ketamine are believed to be related to the change in cortical excitability likely caused by cortical disinhibition ${ }^{5,6}$ and reduction in the activity of inhibitory interneurons. ${ }^{7}$ Acute changes in cortical excitability and glutamate release are proposed to initiate a sequence of biochemical and structural changes within cortical networks. ${ }^{8,9}$ The abnormality may occur in people with bipolar tendency, whose glutamate receptors are hypersensitive or glutamate is overreleasing.

This case suggests a possible relationship between manic symptoms under recreational dosage and administration route of ketamine. According to the previous studies, ${ }^{2,10,11}$ subanesthetic dose via intravenous-administered ketamine had rapid and robust antidepressant effects. Transient manic-like symptoms were noted in a few bipolar and unipolar depressed patients, but this transient mood elevation seems inconsistent with a persistent substance-induced syndrome. ${ }^{12,13}$ That is, in these studies, the transient elevated mood did not meet the criteria for mania, in terms of the disease duration or the number of symptoms. Only one case report ${ }^{3}$ shows the possibility of the induction of mania in a patient receiving intravenous ketamine therapy. However, the effect of multiple medication adjustments cannot be excluded.

There were some limitations in this case. First, bipolar tendency could not be entirely excluded in this patient although manic or hypomanic symptoms were not noted under antidepressant treatment. Second, we did not conduct screen tests for multi-substances; therefore, we could not prove the validity of his self-report.

To the best of our knowledge, this is the first report regarding mania after recreational use of ketamine. Further research is warranted to replicate this finding and to elucidate the possible mechanism of ketamine-related mania symptoms. If the finding can be confirmed in the future, physicians should pay attention to manic symptoms in patients abusing ketamine.

\section{Disclosure}

The authors report no conflicts of interest in this work.

\section{References}

1. DiazGranados N, Ibrahim LA, Brutsche NE, et al. Rapid resolution of suicidal ideation after a single infusion of an N-methyl-D-aspartate antagonist in patients with treatment-resistant major depressive disorder. $J$ Clin Psychiatry. 2010;71(12):1605-1611.

2. Caddy C, Giaroli G, White TP, et al. Ketamine as the prototype glutamatergic antidepressant: pharmacodynamic actions, and a systematic review and meta-analysis of efficacy. Ther Adv Psychopharmacol. 2014;4(2):75-99.

3. Ricke AK, Snook RJ, Anand A. Induction of prolonged mania during ketamine therapy for reflex sympathetic dystrophy. Biol Psychiatry. 2011;70(4):e13-e14.

4. Corazza O, Assi S, Schifano F. From "special K" to "special M": the evolution of the recreational use of ketamine and methoxetamine. CNS Neurosci Ther. 2013;19(6):454-460.

5. Maeng S, Zarate CA Jr, Du J, et al. Cellular mechanisms underlying the antidepressant effects of ketamine: role of alpha-amino-3-hydroxy5-methylisoxazole-4-propionic acid receptors. Biol Psychiatry. 2008;63:349-352.

6. Quirk MC, Sosulski DL, Feierstein CE, et al. A defined network of fast-spiking interneurons in orbitofrontal cortex: responses to behavioral contingencies and ketamine administration. Front Syst Neurosci. 2009;3:13.

7. Homayoun H, Moghaddam B. NMDA receptor hypofunction produces opposite effects on prefrontal cortex interneurons and pyramidal neurons. J Neurosci. 2007;27:11496-11500.

8. Duman RS, Aghajanian GK. Synaptic dysfunction in depression: potential therapeutic targets. Science. 2012;338:68-72.

9. Li N, Lee B, Liu RJ, et al. mTOR-dependent synapse formation underlies the rapid antidepressant effects of NMDA antagonists. Science. 2010;329:959-964.

10. Zarate CA Jr, Singh JB, Carlson PJ, et al. A randomized trial of an $\mathrm{N}$-methyl-D-aspartate antagonist in treatment-resistant major depression. Arch Gen Psychiatry. 2006;63:856-864.

11. Zarate CA Jr, Brutsche NE, Ibrahim L, et al. Replication of ketamine's antidepressant efficacy in bipolar depression: a randomized controlled add-on trial. Biol Psychiatry. 2012;71:939-946.

12. Niciu MJ, Luckenbaugh DA, Ionescu DF, et al. Subanesthetic dose ketamine does not induce an affective switch in three independent samples of treatment-resistant major depression. Biol Psychiatry. 2013; 74(10):e23-e24.

13. Murat A, Amit A. Reply to: subanesthetic dose ketamine does not induce an affective switch in three independent samples of treatment-resistant major depression. Biol Psychiatry. 2013;74(10):e25. 


\section{Publish your work in this journal}

Neuropsychiatric Disease and Treatment is an international, peerreviewed journal of clinical therapeutics and pharmacology focusing on concise rapid reporting of clinical or pre-clinical studies on a range of neuropsychiatric and neurological disorders. This journal is indexed on PubMed Central, the 'PsycINFO' database and CAS, and is the official journal of The International Neuropsychiatric Association (INA). The manuscript management system is completely online and includes a very quick and fair peer-review system, which is all easy to use. Visit http://www.dovepress.com/testimonials.php to read real quotes from published authors.

\footnotetext{
Submit your manuscript here: http://www.dovepress.com/neuropsychiatric-disease-and-treatment-journal
} 